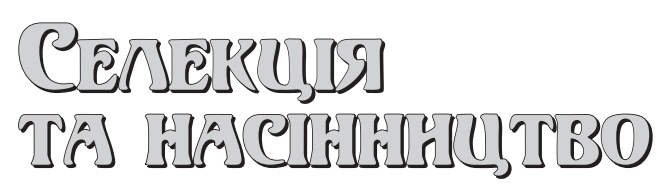

\title{
Characteristics of productivity of soft winter wheat samples from Common Bunt-Resistant Nursery (CBUNT-RES) in the southern Forest-Steppe zone of Ukraine
}

\author{
S. M. Kholod ${ }^{*}$, M. V., Kirian, R. S. Vyskub \\ Ustymivka Experimental Station of Plant Production of Plant Production Institute nd. a. V. Ya. Yuriev, NAAS of Ukraine, \\ 15 Akademika Vavylova St., Ustymivka, Hlobyno district, Poltava region, 39074,Ukraine, "e-mail: svitlanakholod77@ukr.net
}

Purpose. Evaluate the introduced samples of soft winter wheat from the international nursery Common Bunt-Resistant Nursery (CBUNT-RES) of different ecological and geographical origin in the southern part of the Forest-Steppe zone of Ukraine according to a set of productivity indicators in order to define the most valuable samples and describe them. Methods. During 2016-2019 on the base of Ustymivka Experimental Station for Plant Production of the V. Ya. Yuriev Plant Production Institute of NAAS the authors studied, evaluated and described 75 new soft winter wheat samples of various eco-geographical origins by productivity traits. In the field and laboratory conditions, indicators of yield and productivity were determined: 1000 grains weight, plant height and ear length, the number of spikelets and grains in the ear, weight of ear and grain and early-ripening. Results. Plant material with increased parameters of economic and biological characters was identified. During studies, it was found that 'F08347G8', 'F00628G34-1' (Romania), '91-142A61/KATIA1//GRISET-4', 'SAULESKU\#44/TR810200//GRISET-4', 'ATTILA/BABAX//PASTOR/4/...' (IU067591) (Turkey), 'INTENSIVNAYA//PBW343*2/ TUKURU', 'SANZAR-8/KKTS' (Mexico) were the high-yielding varieties. The samples of soft winter wheat as 'F08347G8', 'F00628G34-1' (Romania), 'INTENSIVNAYA//PBW343*2/...' (IU067637) (Mexico), 'ATAY/GALVEZ87/6/TAST/...' (IU067587), ‘DE9/MERCAN-2', 'KRASNODAR/FRTL/6...' (IU067595), 'SAULESKU\#44/TR810200//GRISET-4', 'GANSU-1/3/AUSGS50AT34/...' (IU067598), ‘ORKINOS-1*2/3/AUS...' (IU067608), 'KAMBARA1/ZANDER-17' , 'TAM200/KAUZ/4/CHAM6//...' (IU067612) (Turkey) contained a large grain weight (more than $5.0 \mathrm{~g}$ ), plant productivity in these samples was rather high due to increased amount of grains and the thousand kernel weight. Conclusions. The introduced soft winter wheat samples of various eco-geographical origins were adapted to the Southern Forest-Steppe and can be recommended as a source material in breeding to increasing productive capacity.

Keywords: soft winter wheat; productivity; valuable economic character; source material.

\section{Introduction}

Wheat is being grown all over the world. It is the main food product for about $35 \%$ of the world's population and occupies an important place among cereals [1]. An important way to increase wheat production today is to expand its genetic diversity and analyze key traits [2].

In terms of sown areas and grain production, soft winter wheat occupies a leading po-

\section{Svitlana Kholod}

http://orcid.org/0000-0002-2443-0879

Viktor Kirian

http://orcid.org/0000-0001-8730-8507

Roman Vyskub

http://orcid.org/0000-0001-7679-2188 sition in Ukraine [3]. It is sown in areas with different climatic conditions. An effective way to increase the gross yield of wheat is to create and introduce new highly productive, plastic, stable and disease-resistant varieties into agricultural production. An important guarantee for the creation of varieties is the constant search for a new soft winter wheat source material for breeding. Therefore, the search, introduction and inclusion of new samples to the breeding process is of great importance [4].

In the worldwide gene pool of wheat, there are a significant number of varieties and forms that can be used as a source of initial material for some traits and properties [5]. Among the main conditions for successful 
breeding is the use of genetically diverse source material of various ecological and geographical origin with a complex of valuable traits and properties [6, 7]. Creation of new varieties and hybrids with a high level of productivity, quality and adaptability to growing conditions is based on the effective use of genetic diversity of cultivated plants $[8,9]$. To maximize the potential of this crop, varieties of both domestic and foreign (to improve quality and productivity) breeding are used [10]. Thus, it is important to evaluate the varieties, lines and hybrid forms of winter wheat of the worldwide gene pool in the nurseries of the CIMMYT and ICARDA breeding centers according to the main biological and economic characteristics [11, 12].

The purpose of the research is to evaluate introduced samples of soft winter wheat of various ecological and geographical origin from the international nursery Common BuntResistant Nursery (CBUNT-RES) in the southern part of the Forest-Steppe of Ukraine according to a set of productivity indicators in order to define the most valuable samples and describe them.

\section{Materials and research methods}

Field and laboratory studies were carried out in the introduction-quarantine and collection nurseries on the base of Ustymivka Experimental Station for Plant Production of the Plant Production Institute nd. a. V. Ya. Yuriev of NAAS (hereinafter - UESPP) during 2016-2019 (Ustymivka, Hlobyno district, Poltava region - location $49^{\circ} 18^{\prime} 21^{\prime \prime} \mathrm{N}, 33^{\circ} 13^{\prime} 56^{\prime \prime} \mathrm{E}$, $94 \mathrm{~m}$ a.s.l).

The initial material for the research was ecologically and geographically distant varieties, lines and hybrid forms of soft winter wheat from the international nursery Common Bunt-Resistant Nursery (CBUNT-RES), which were brought from the Turkish branch [International Winter Wheat Improvement Program (IWWIP), which is a joint breeding program of Republic of Turkey Ministry of Food, Agriculture and Livestock, the International Maize and Wheat Improvement Center (CIMMYT) and the International Center for Agricultural Research in the Dry Areas (ICARDA)]. The nursery includes 75 specimens from 7 countries participating in these tests (Turkey, Iran, Kazakhstan, Mexico, Romania, USA and Russia).

Sowing was carried out on plots of $2 \mathrm{~m}^{2}$ in a row with $15 \mathrm{~cm}$ between-row spacing at a seeding rate of 400 grains per $1 \mathrm{~m}^{2}$. The national variety 'Smuhlianka' (semi-dwarf)
(Ukraine) and international standard varieties 'Gerek 79', 'Mufitbey', 'Nacibey' (Turkey) were the standards for soft winter wheat. For the standards of large grain size, early-ripening and stable grain productivity the standard varieties 'Ukrainka odeska' and 'Donskaya polukarlykovaya' were taken.

During the growing season, observations and descriptions of samples were carried out in accordance with the recommendations for the study of foreign samples of agricultural crops in the introduction-quarantine nurseries [13] and Methodical instructions on studying a collection of wheat [14]. In the field, in the phase of full ripeness, plant lodging resistance was determined, the height of the plants, the total and productive tillering were measured. In laboratory conditions, structural analysis was carried out for such quantitative characteristics as the length of the ear, number of spikelets and grains in the ear, weight of grain from the ear and from the plant, yield according the gradations of the $C M E A$ wide-range unified classifier of the genus Triticum L. [15]. The experimental data were statistically analyzed using Microsoft Excel.

Soft winter wheat was sowed in the first decade of October $(5,9,10$ numbers, respectively) in 2016-2018. The weather conditions prevailing at the beginning of October 2016, 2017 and 2018 contributed to the uniform emergence of seedlings of soft winter wheat plants (Table 1). In 2016 the average daily temperature during this period was $7.1{ }^{\circ} \mathrm{C}$, in $2017-9.5{ }^{\circ} \mathrm{C}$, and in $2018-11.7{ }^{\circ} \mathrm{C}$. Plants resumed their growth in the first decade of March 2017, the third decade of March 2018 and the first decade of March. 2019. May, which marked the beginning of earing of the overwhelming majority of samples, was accompanied in 2017 and 2018 by an average, and in 2019 by a sufficient amount of precipitation $(30.6 ; 27.7$ and $130.7 \mathrm{~mm}$, respectively) and a temperature of $0.6{ }^{\circ} \mathrm{C}$ (in 2017), $4.4{ }^{\circ} \mathrm{C}$ (in 2018) and $2.0^{\circ} \mathrm{C}$ (in 2019) are higher than the average perennial indicators.

During the formation, milky ripening and maturation of grain, the average daily temperature in June and July, 2017 was 21.9 and $22.5{ }^{\circ} \mathrm{C}$, in $2018-22.2$ and $23.8^{\circ} \mathrm{C}$, and in $2019-24.5$ and $22.3{ }^{\circ} \mathrm{C}$ respectively. The amount of precipitation in these months in 2017 was 14.7 and $92.2 \mathrm{~mm}$, in $2018-31.8$ and $47.9 \mathrm{~mm}$, in $2019-62.7$ and $56.3 \mathrm{~mm}$, respectively (according to the UESPP weather station). 
Table 1

Hydrothermal regime during the years of soft winter wheat research (2016-2019)

\begin{tabular}{|l|c|c|c|c|c|c|c|c|}
\hline \multirow{2}{*}{ Month } & \multicolumn{4}{|c|}{ Precipitation, $\mathrm{mm}$} & \multicolumn{3}{c|}{ Average daily air temperature, ${ }^{\circ} \mathrm{C}$} \\
\cline { 2 - 8 } & $\begin{array}{c}\text { average } \\
\text { perennial }\end{array}$ & $2016 / 2017$ & $2017 / 2018$ & $2018 / 2019$ & $\begin{array}{c}\text { average } \\
\text { perennial }\end{array}$ & 2016/2017 & 2017/2018 & $2018 / 2019$ \\
\hline August & 58 & 65.6 & 3.7 & 3.2 & 19.8 & 22.8 & 24.8 & 26.0 \\
September & 56 & 6.3 & 36.1 & 50.4 & 14.4 & 16.5 & 18.1 & 18.5 \\
October & 39 & 83.2 & 50.5 & 16.3 & 8.1 & 7.1 & 9.5 & 11.7 \\
November & 49 & 80.8 & 29.8 & 32.0 & 2.0 & 1.6 & 3.4 & 0.2 \\
December & 35 & 42.3 & 79.4 & 114.2 & -2.7 & -0.6 & 3.6 & -1.7 \\
January & 38 & 48.0 & 40.1 & 62.2 & -4.9 & -5.8 & -2.6 & -5.0 \\
February & 30 & 22.7 & 41.4 & 21.2 & -4.5 & -2.2 & -3.2 & 0.2 \\
March & 28 & 9.9 & 103.9 & 18.1 & 0.5 & 6.0 & -1.8 & 4.8 \\
April & 44 & 15.9 & 9.8 & 28.6 & 8.9 & 11.5 & 13.8 & 11.6 \\
May & 50 & 30.6 & 27.7 & 130.7 & 15.9 & 16.5 & 20.3 & 18.5 \\
June & 57 & 14.7 & 31.8 & 62.7 & 19.5 & 21.9 & 22.2 & 24.5 \\
July & 72 & 92.2 & 47.9 & 56.3 & 21.0 & 22.5 & 23.8 & 22.3 \\
\hline During the period & 556 & 512.2 & 502.1 & 595.9 & 8.2 & 9.8 & 11.0 & 10.9 \\
\hline
\end{tabular}

\section{Results and discussion}

The studied samples of soft winter wheat showed a significant diversity in the evaluated morphological and economic traits (Table 2). In the Forest-Steppe zone of Ukraine, the most important limiting factors for winter wheat growing are overwintering conditions: low temperatures at the depth of the tillering node, ice crust, frequent thaws, and significant changes in daily temperatures in spring. During the years of the study, the overwintering weather conditions were rather mild for the introduced soft winter wheat samples.

The level of valuable economic traits manifestation in soft winter wheat samples

Table 2

(2016-2019)

\begin{tabular}{|c|c|c|c|c|c|c|}
\hline \multirow{2}{*}{\multicolumn{2}{|c|}{ Sign }} & \multicolumn{5}{|c|}{ Level of signs manifestation } \\
\hline & & $x$ & $\min$ & $\max$ & $\mathrm{R}(\max -\min )$ & $\mathrm{V}, \%$ \\
\hline \multicolumn{2}{|l|}{ Productivity, $\mathrm{g} / \mathrm{m}^{2}$} & 742.6 & 473.6 & 973.6 & 500.0 & 13.0 \\
\hline \multirow{3}{*}{ Vegetation period, days: } & seedlings-ripening & 260.2 & 257.0 & 265.0 & 7.6 & 0.6 \\
\hline & seedlings-earing & 222.7 & 219.0 & 227.0 & 8.3 & 0.8 \\
\hline & earing-ripening & 38.5 & 36.0 & 41.3 & 5.3 & 2.6 \\
\hline \multicolumn{2}{|l|}{ Thousand kernel weight, q } & 42.8 & 36.6 & 49.6 & 13.0 & 7.6 \\
\hline \multicolumn{2}{|l|}{ General tillering, stems } & 2.6 & 1.2 & 4.3 & 3.1 & 22.3 \\
\hline \multicolumn{2}{|l|}{ Productive tillering, stems } & 2.5 & 1.2 & 4.1 & 2.9 & 22.3 \\
\hline \multicolumn{2}{|l|}{ Plant productivity, g } & 4.8 & 2.0 & 6.8 & 4.8 & 30.5 \\
\hline \multicolumn{2}{|l|}{ Grain weight per spike, g } & 2.3 & 1.2 & 4.7 & 3.6 & 25.6 \\
\hline \multicolumn{2}{|c|}{ Number of productive spickelets per ear, pcs. } & 18.1 & 12.2 & 23.0 & 10.8 & 12.7 \\
\hline \multicolumn{2}{|c|}{ Number of grains in an ear, pcs. } & 47.6 & 24.0 & 65.8 & 41.8 & 21.3 \\
\hline \multicolumn{2}{|l|}{ Ear length, $\mathrm{cm}$} & 9.2 & 5.4 & 12.8 & 7.4 & 15.6 \\
\hline \multicolumn{2}{|l|}{ Plant height, $\mathrm{cm}$} & 97.7 & 61.0 & 123.3 & 62.3 & 11.7 \\
\hline \multicolumn{2}{|l|}{ Lodging, score } & 8.5 & 5.0 & 9.0 & 4.0 & 13.2 \\
\hline
\end{tabular}

Note. $X$, min max - average, minimum and maximum values, respectively; $R$ (max-min) - range of variation; $\mathrm{V}$ - coefficient of variation. Total tillering - number of all stems on one plant; productive tillering - number of productive stems on a plant; plant productivity - grain weight per plant.

One of the main indicators of the suitability of a winter wheat variety is the length of the growing season. This important indicator has fairly large amplitude of fluctuations, which is due to both genetic characteristics and a set of external growing conditions. Winter wheat varieties with a short growing season are most suitable for cultivation in many regions of Ukraine. M. I. Vavylov [16] pointed out the need for accelerated plant development in arid southern regions in order to avoid the impact of dry winds in summer, and rust damage in areas with excessive moisture. All this forces us to pay more attention to the breeding of early-ripening forms [17]. Varieties with a short period of sprouting and earing are especially valuable for early-ripening breeding [18]. During the investigation, this period was 219- 
220 days in the early-ripening reference variety 'Donskaya polukarlikovaya'. Among the introduced soft winter wheat samples, the following samples were distinguished by a short sprouting- heading interphase period: 'ATAY/ GALVEZ87/6//...' (IU067587), ‘SAULESKU\#44/ TR810200//...' (IU067590), 'SHARK/ F4105W2.1//...' (IU067597), 'GANSU-1/3/AUSGS50AT34/...' (IU067598), 'BURBOT-4/3/OMBUL/...' (IU067599), ‘SAULESKU\#44/TR810200// IZGI' (IU067610) (Turkey), 'F00628G34-1', 'F06393GP10', 'F08034G1' (Romania), 'KS92WGRC-25’, 'AMSEL/KS970274/3/...' (IU067639), 'TSAPKI/FARMEC', 'INTENSIVNAYA// PBW343*2/TUKURU', 'SANZAR-8/KKTS' (USA), 'SPN/MCD//CAMA/3/NZR/4/...' (IU067628), 'SON64/4/ WR51/MIDA//NT.H/3/...' (IU067626) (Iran). The above samples sprouted 1-3 days earlier than the standard or together with it.

The duration of the germination-maturation period varied from 257 to 265 days, the coefficient of variation was low $(0.58 \%)$. The duration of the period from germination to maturity for the early-ripening standard 'Donskaya polukarlikovaya' averaged 257 days. According to the seedlings-maturation sign, the maximum number of samples was 52 , or $71.2 \%$ refers to the period, which was 259-261 days. In recent years, during the period of ear formation, there was a significant deficit of precipitation, an increase in the average daily temperature up to $30{ }^{\circ} \mathrm{C}$, atmospheric drought combined with ground drought, and a decrease in the content of moisture available to plants to a critical value. Considering this, geographically distant early-ripening samples, for example, 'TSAPKI/FARMEC' (IU067638) 'AMSEL/ KS970274/3/KS91048L-2-1/..'’

(IU067639)

(Mexico), 'KS92WGRC-25' (CWA), 'SPN/MCD// CAMA/3/NZR/4/...' (IU067628), 'ALMT*3/7/ VEE/CMH77A.917//...' (IU067634) (Iran), 'SHARK/F4105W2.1//...' (IU067597), 'GANSU-1/ 3/AUS GS50AT34/...' (IU067598), ‘362K2.111// TX71A1039.VI*3/...' (IU067603), 'SELYANKA/ MERCAN-1', 'SHARK/F4105W2.1//...' (IU067613), 'BATERA//KEA/TOW/3...' (IU067617), ‘ADMIS/5/SMB/HN4//...' (IU067622) (Turkey), etc. can be promising for the creation of the initial material of soft winter wheat, resistant to summer drought and high temperatures. Earlyripening samples of soft winter wheat, characterized by increased productivity, are valuable for breeding. Among wheat samples with a shortened growing season (258-259 days), increased yield (8.0-9.0 t/ha) was shown by the following samples: 'F08347G8', 'F00628G34-1' (Romania), 'SAULESKU\#44/TR810200//GRISET-4', '91-142A 61/KATIA1//GRISET-4' (Tur- key), 'INTENSIVNAYA//PBW343*2/TUKURU', 'SANZAR-8/KKTS' (Mexico).

An important characteristic of most winter grain crops is the relationship between plant height and lodging resistance. Lodging of wheat crops makes it difficult to harvest, leads to losses during threshing. Lodging resistance of new wheat samples was evaluated before harvesting. It was revealed that the height of the plant is not decisive and the only factor that determines this indicator. High resistance to lodging before harvesting (8-9 points) was found in 69 samples, which allows using them in breeding programs in the presence of other valuable traits. Changes in this indicator were in the range of $5-9$ points. The following samples were resistant to lodging in the full maturation phase: 'SHARK/F4105W2.1//...' (IU067597), '87-461A63-555/4/ERIT58-87//...' (IU067609), 'ORKINOS-1/4/JING411//PLK70/LIRA ...' (IU067619) (Turkey), 'AMSEL/KS970274/3/...' (IU067639), 'MRS/CI14482//YMH/HYS/3/...' (IU067642) (USA), 'F06393GP10', 'F08034G1', 'F08347G8', 'F00628G34-1' (Romania), etc. High resistance to lodging (9 points) samples 'QUDS*3/MV17'(Iran), 'DORADE-5/KS980512', 'OR943576/KS920709' (CWA), 'BURBOT-4/3/ OMBUL/ALAMO//...' (IU067592) 'KRASNODAR/FRTL/6/NGDA...' (IU067595) (Turkey) combine with high winter hardiness and productivity; 'SANZAR-8/KKTS', 'INTENSIVNAYA// PBW343*2/TUKURU', (Mexico), 'SHARK/ F4105W2.1//CHARA/...' (IU067597), 'GANSU-1/3/AUSGS50AT34/SUNCO//...' (IU067598), '91-142A61/KATIA1//GRISET-4' (IU067605) (Turkey) showed also the traits of early-ripening and high productivity.

Plant height is a genetically determined trait; however, agroclimatic environmental factors also affect its formation in a particular variety [19]. Among the studied wheat samples, 14 high-growth ones (19.2\%) were identified, in which this indicator was within $111-128 \mathrm{~cm}$. The maximum number of samples $27 \mathrm{pcs}$. each $(37.0 \%)$ belonged to groups with plant heights of 96-110 cm and 81-95 cm (medium-sized forms), 5 pcs. $(6.8 \%)$ belonged to the group of undersized $(66-80 \mathrm{~cm})$. The medium-sized group also includes international standard varieties: 'Gerek 79', 'Mufitbey', 'Nacibey' (Turkey). Plant height is not only a varietal morphological trait, but also an indicator of plant resistance to lodging. The plant's resistance to lodging depends on the height and anatomical properties of the stem [20]. Short-stemmed specimens of winter wheat with a plant height of $70-90 \mathrm{~cm}$ are quite resistant to lodging almost regardless of the stem thickness, while 
forms with a plant height of $90-100 \mathrm{~cm}$ are moderately resistant [21]. Most of the specimens had a high resistance to lodging, which is due to the short stem and strength of the straw.

Productivity is one of the most important characteristics that determines the economic value of a variety. It is known that the amount of grain yield is an integral indicator of plant productivity, directly depends on the quantitative expression of each structural element and environmental conditions [18]. We analyzed such elements of the productivity structure as the length of the ear, the rate of productive tillering, the number of spikelets and the number of grains from the ear, the weight of the grain from the ear, the thousand kernel weight.

A fairly valuable quantitative trait is productive tillering, which directly affects the size of the yield. Depending on the varietal characteristics, the coefficient of productive tillering in the samples was 1.2-4.1 stems (from low to high), the range of variation was 2.9 stems, the coefficient of variation reached $22.3 \%$. On this basis, the introduced material is distributed as follows: 14 samples $(19.2 \%)$ had a very low coefficient of productive tillering (1.6-2.0), 51 samples $(69.9 \%)$ - low (2.1$3,0)$ and 8 samples $(10.9 \%)$ - medium (3.1-4.1). The highest values of this indicator were in the samples: 'DORADE-5/KS980512' (USA), 'KRASNODAR/FRTL/6/...' (IU067595), 'GANSU-1/3/ AUSGS50AT34/...' (IU067598), 'DE9/MERCAN-2', 'KRASNODAR/FRTL/6/NGDA146...' (IU0675607) (Mexico), 'QUDS*3/MV17' (Iran), 'INTENSIVNAYA// PBW 343*2/TUKURU' (Mexico).

The spike length is characterized by a clear phenotypic manifestation and is an important trait in breeding for productivity [22]. On average, over the years of the study, it ranged from 5.4 to $12.8 \mathrm{~cm}$, the range of variation was $7.4 \mathrm{~cm}$, average variability was observed (the coefficient of variation was $15.57 \%$ ). 10 samples $(13.7 \%)$ with a short ear $(5.4-7.5 \mathrm{~cm}), 47$ $(64.3 \%)$ - with an average $(7.6-10.5 \mathrm{~cm})$ and 16 samples $(21.9 \%)$ - with a long ear $(10.6-13.5 \mathrm{~cm})$. Samples with the spike length over $11.0 \mathrm{~cm}$ were the most valuable; this list included: 'ATAY/ GALVEZ87/6/TAST/SPRW/4...' (IU067587), ' M A D SE N / M A L C OL M / Z A R G A N A ...' (IU067588), 'RINA-6/ORKINOS-7' (IU066050), 'SAULESKU\#44/TR810200//...' (IU067590), ‘TJB368-251/BUC//SMUT1590-165/...' (IU067596), 'DE9/MERCAN-2' (IU067601), 'BATERA// KEA/TOW/3/TAM200' (IU067617), 'KAMBARA1/ZANDER-17' (IU067621), 'ADMIS/5/ SMB/HN4//...' (IU067622) (Turkey), 'BEZOS-
TAYA1/AE.CYLINDRICA' (IU067644), 'BEZOSTAYA1/TR.MILITINAE//TR...'(IU067645) (Kazakhstan), 'CV.RODINA/AE.SPELTOIDES ...' (IU067647) (Russia). Among the standard varieties, a long ear was in 'Smuhlianka' 'and 'Mufitbey' - 8,8 and $10.4 \mathrm{~cm}$, respectively.

The number of grains per ear is one of the main indicators of productivity, which in turn depends on the number of spikelets per ear. This indicator for soft winter wheat samples ranged from 12.2 to 23.0 pcs., The coefficient of variation $12.7 \%$. By the number of spikelets per ear (pcs.) the following samples were identified: 'ATAY/GALVEZ87/6/TAST/SPRW/4/...' (IU067587) - 21,4, 'RINA-6/ORKINOS-7' 23,0, 'DE9/MERCAN-2' - 20,6, 'KRASNODAR/FRTL/6/...' (IU067601) - 20,6 (Turkey), 'ALMT*3/7/VEE/CMH77A.917//...' (IU067634) - 21,0 (Iran), 'BEZOSTAYA1/AE.CYLINDRICA' (IU067644) - 22,4 (Kazakhstan), etc.; standards 'Smuhlianka' and 'Mufitbey' - 17.6 and 20.4 , respectively. Over the years of research, under the influence of various conditions, the number of grains per spike in the introduced samples was in the range from 24.0 to 65.8 grains, the range of variation was 41.8 grains; there was significant variability (coefficient of variation $-21.3 \%$ ) of this indicator depending on the genotype of the samples. Eleven samples $(15.1 \%)$ had a low grain content per ear (24.0-35.0 grains), an average (35.1-45.0 grains) - 17 (23.3\%), a high (45.1-65.0) - 44 samples $(60.3 \%$ of the total). Some samples were characterized by a fairly high level of grain number per ear - 60-65 grains, in particular: '87-461a63-555//...' (IU067585) - 60,0, 'RINA-6/ORKINOS-7' - 65,4, 'ATAY/GALVEZ87/6/...'(IU067587)-62,8, ‘SAULESKU\#44/ TR810200//GRISET-4' - 65,4, 'BATERA// KEA/TOW/3//...' (IU067617) - 61,2, 'ORKINOS-1/4/JING411//...' (IU067619) (Turkey) 61,4, 'ALMT*3/7/VEE/CMH77A.917/'(IU067634) (Iran) - 60,0, 'F07270G2' (Romania) - 61,4, 'BEZOSTAYA1/AE.CYLINDRICA' (Kazakhstan) $-65,8$ grains. The highest grain number among the standards and etalons had the varieties 'Ukrainka odeska' and 'Mufitbey' (depending on the year $-47-56$ grains).

Increasing the yield of grain per ear is a prerequisite for increasing the potential yield of the variety. This indicator depends on many factors: temperature, humidity, nutritional conditions, varietal characteristics [23]. Over the years of research, this indicator ranged from 1.2 to $4.7 \mathrm{~g}$, the range of variation was $3.6 \mathrm{~g}$, and the coefficient of variation was $25.6 \%$. Among the introduced material, 12 samples (16.4\%), with grain weight per ear from 
1.1 to $1.7 \mathrm{~g}, 20$ samples $(27.4 \%)-1.8-2.2 \mathrm{~g}$, 41 samples $(56.2 \%)-2.3-3.0 \mathrm{~g}$ were identified. Among the standards, 'Lisova pisnia' variety had the highest productivity $(2.3-2.7 \mathrm{~g})$.

The grain weight per plant in soft winter wheat samples varied from 2.0 to $6.8 \mathrm{~g}$, or an average of $4.1 \mathrm{~g}$. The following samples belonged to the best in terms of productivity (4.5-4.9 g): 'ATTILA/BABAX//PASTOR/4...' (IU067591), '91-142A61/KATIA1//GRISET-4' (IU067605), 'KRASNODAR/FRTL/6/...' (IU067611), 'SAULESKU \#44/TR810200// IZGI' (IU067610), 'SANZAR-8/KKTS' (Turkey), 'F06393GP10', 'F07270G2' (Romania).

A large weight of grain per spike (more than $5.0 \mathrm{~g})$ was found in samples 'F08347G8', 'F00628G34-1', F00628G34-1' (Romania), 'INTENSIVNAYA//PBW343*2/...' (IU067637) (Mexico), 'ATAY/GALVEZ 87/6/TAST/...' (IU067587), 'SAULESKU\#44/TR810200//GRISET-4', 'KRASNODAR/FRTL/6...' (IU067595), 'GANSU-1/3/AUSGS50AT34/...' (IU067598), 'DE9/ MERCAN-2', 'ORKINOS-1*2/3/AUS...'(IU067608), 'KAMBARA1/ZANDER-17', 'TAM200/ KAUZ/ 4/CHAM6//...' (IU067612) (Turkey), which have a fairly high productivity of the plant due to increased grain content, and the thousand kernel weight. The mass of grain per plant for the standards 'Ukrainka odeska', 'Smuhlianka', 'Donskaya polukarlykovaya', 'Lisova pisnia', 'Gerek 79', 'Mufitbey', 'Nacibey' varied over the years within $3.2-3.6 ; 3.2-3.9 ; 3.5-4.2$; $3.6-4.5 ; 4.5-5.5 ; 3.5-3.9$ and $5.5-5.9 \mathrm{~g}$, respectively.

The thousand kernel weight is an important element of the crop structure, which characterizes the grain size and fullness [22]. Growing conditions, precipitation, temperature during grain ripening, as well as biological characteristics of the variety are of decisive importance for the formation of this indicator. During the years of research, the thousand kernel weight varied from 36.6 to $49.6 \mathrm{~g}$, the average value was $42.8 \mathrm{~g}$, the range of variation was $13.0 \mathrm{~g}$, and the coefficient of variation was $7.6 \%$. Six samples $(8.2 \%)$ had a low thousand kernel weight (31.0-38.0 g), 55 samples (75.3\%) had an average weight $(39.0-46.0 \mathrm{~g})$, and a large weight (47-54.0) - 12 samples $(16.4 \%$ of the total). The samples 'ATAY/GALVEZ87/6/...' (IU067587) (48,0 g), 'ATTILA/BABAX//...' (IU067591) (46,4 g), 'KRASNODAR/FRTL/6/...' (IU067595) (46,8 g), GANSU-'1/3/AUSGS50AT34/...' (IU067598) (46,7 g), '362K2.111// TX71A1039.VI*3/...' (IU067603) (46,5 g), 'KRASNODAR/FRTL/6/...' (IU067607) (47,8 g) 'SAULESKU\#44/TR810200//IZGI' (46,9 g), 'TAM200/KAUZ/4/CHAM6//...' (IU067612)
(48,9 g), 'KAMBARA1/ZANDER-17' (47,5 g) Turkey, 'SON64/4/WR51/MIDA//...'(IU067626) $(49,1 \mathrm{~g})$ - Iran, 'SANZAR-8/KKTS' (IU067636) $(45,4$ g), 'INTENSIVNAYA//PBW343*2/TUKURU' (IU067637) (47,8 g) - Mexico, 'AMSEL/ KS970274/3/...' (IU067639) (48,8 g), 'KS92WGRC-25' (46,4 g) - USA, 'F06393GP10' (46,1 g), 'F08034G1 (46,6 g), 'F08347G8' (49,6 g) - Romania. In the standard of large size grain variety 'Donskaya polukarlykovaya', the thousand kernel weight was $40.1 \mathrm{~g}$; in national standard 'Smuhlianka' it was 39.3 , in the international standard 'Mufitbey' - 49.5 g.

Wheat grain yield depends on many factors, primarily environmental onditions. Overwintering conditions and moisture supply during the spring-summer growing season contributed to the normal growth and development of soft winter wheat plants, which had a positive effect on the yield. The analysis of the average yield over the years of research indicates that the following samples belonged to the most productive variety 'F08347G8', 'F00628G34-1' (Romania), 'SAULESKU\#44/TR810200//GRISET-4', 'ATTILA/BABAX//PASTOR/4/...' (IU067591), ‘91-142A61/KATIA1//GRISET-4' (Turkey), 'INTENSIVNAYA//PBW343*2/TUKURU', 'SANZAR-8/KKTS' (Mexico), which exceeded the best of the national standards 'Smuhlianka' by $22-80 \%$.

As a result of the study of a new introduced material of soft winter wheat, samples with a high and optimal level of manifestation of signs were identified:

- yield $\left(>850 \mathrm{~g} / \mathrm{m}^{2}\right)$ (for the standard variety 'Smuhlianka' - $800.7 \mathrm{~g} / \mathrm{m}^{2}$ ), number of grains per ear (> 50.0 grains), grain weight per ear $(>2.0 \mathrm{~g})$, plant productivity $(>3.5 \mathrm{~g})$ and thousand kernel weight (> 45.0 g) - 'F08347G8', 'F00628G34-1' (Romania), 'GANSU-1/3/AUSGS50AT34/SUNCO//...' (IU067598), 'ATTILA/ BABAX//PASTOR/4/...' (IU067591) (Turkey);

- yield $\left(>850 \mathrm{~g} / \mathrm{m}^{2}\right)$ (for the standard variety 'Smuhlianka' - $\left.800.7 \mathrm{~g} / \mathrm{m}^{2}\right)$, plant productivity $(>3.5 \mathrm{~g})$, thousand kernel weight $(>45.0 \mathrm{~g})$ and early-ripening (257-258 days) - 'INTENSIVNAYA//PBW343*2/TUKURU' (IU067637), 'SANZAR-8/KKTS' (IU067636) (Mexico);

- number of grains per ear (>50.0 grains), grain weight per ear $(>2.0 \mathrm{~g})$, plant productivity $(>3.5 \mathrm{~g})$ and thousand kernel weight $(>45.0 \mathrm{~g})-$ 'SAULESKU\#44/TR810200//...' (IU067590), 'KAMBARA1/ZANDER-17' (IU067621), 'KRASNODAR/FRTL/6/NGDA146/...' (IU067595) (Turkey);

- ear length $(>11.0 \mathrm{~cm})$, number of grains per ear ( $>50.0$ grains), grain weight per ear $(>2.0 \mathrm{~g})$ and plant productivity $(>3.5 \mathrm{~g})$ - 'ATAY/GAL- 
VEZ87/6/TAST/...' (IU067587), 'DE9/MERCAN-2' (IU067601) (Turkey), 'BEZOSTAYA1/ AE.CYLINDRICA' (IU067644) (Kazakhstan);

- number of grains per ear ( $>50.0$ grains), grain weight per ear ( $>$ more than $2.0 \mathrm{~g}$ ) and plant productivity ( $>3.5 \mathrm{~g})$ - 'ORKINOS-1/4/ JING411//...' (IU067619) (Turkey), 'ALMT*3/7/ VEE/CMH77A.917//...' (IU067634) (Iran);

- ear length $(>11.0 \mathrm{~cm})$ and plant productivity $(>3.5 \mathrm{~g})$ - 'MADSEN/MALCOLM//...' (IU067588), 'TJB368-251/BUC //SMUT1590165/...' (IU067596), 'KAMBARA1/ZANDER-17' (IU067621), 'ADMIS/5/SMB/HN4//...'(IU067622) (Turkey);

- number of grains per ear ( $>50.0$ grains) and plant productivity ( $>3.5 \mathrm{~g})$ - 'ALMT*3/7/VEE/ CMH77A.917/...' (IU067634) (Iran), 'F07270G2' (Romania);

- thousand kernel weight ( $>45.0 \mathrm{~g})$ - 'SON64/4/ WR51/MIDA//NT.H/3/K117...' (IU067626) (Iran), 'TAM200/KAUZ/4/CHAM6//..' (IU067612) (Turkey).

\section{Conclusions}

In the process of studying the productivity elements of soft winter wheat samples from the international nursery CBUNT-RES, it was revealed that in the southern part of the ForestSteppe of Ukraine they had a different grain yield - from 4.7 to $9.7 \mathrm{t} / \mathrm{ha}$. Analysis of the average yield over the years of research indicates that high-yielding samples include: 'F08347G8', 'F00628G34-1' (Romania), '91142A61/KATIA1//GRISET-4' 'SAULESKU\#44/ TR810200//GRISET-4' (IU067590), ‘ATTILA/ BABAX//...' (IU067591), 'ATTILA/BABAX// PASTOR/4/...' (IU067605) (Turkey), 'INTENSIVNAYA//PBW343*2/TUKURU' (IU067637), 'SANZAR-8/KKTS' (IU067636) (Mexico). In soft winter wheat samples 'F08347G8', 'F00628G34-1', F00628G34-1' (Romania), 'INTENSIVNAYA//PBW343*2/...' (IU067637) (Mexico), 'ATAY/GALVEZ 87/6/TAST/...' (IU067587), 'SAULESKU\# 44/TR810200//GRISET-4', 'KRASNODAR/FRTL/6...' (IU067595), 'GANSU-1/3/AUSGS50AT34/...' (IU067598), 'DE9/ MERCAN-2', 'ORKINOS-1*2/3/AUS...' (IU067608), 'KAMBARA1/ZANDER-17', 'TAM200/KAUZ/4/ CHAM6//...' (IU067612) (Turkey) the grain weight per plant exceeded $5.0 \mathrm{~g}$. The plant productivity was high due to both increased grain size and the thousand kernel weight. The samples 'ATAY/GALVEZ87/6/TAST/...' (IU067587), 'SAULESKU\# 44/TR 810200//GRISET-4' (IU067590), 'GANSU-1/3/AUSGS50AT34/SUNCO//...' (IU067598), 'DE9/MERCAN-2' (IU067601), 'ORKINOS-1/4/JING411//...' (IU067619) (Turkey 'F00628G34-1', 'F08347G8' (Romania), 'BEZOS-
TAYA1/AE.CYLINDRICA' (Kazakhstan) were selected by a complex of features. The above samples can be recommended as a source of valuable traits for practical use in breeding, and they are also suitable for cultivation in the zone of the Southern Forest-Steppe of Ukraine.

\section{References}

1. Kochmarskyi, V. S., Zamlila, N. P., Volohdina, H. B., Humeniuk, 0. V., \& Voloshchuk, S. I. (2016). Adaptability level of perspective lines of bread winter wheat in the conditions of Forest-Steppe of Ukraine. Mironivs'kij visnik [Myronivka Bulletin], 2, 98-116. [in Ukrainian]

2. Brenchley, R., Spannagl, N., Pfeifer, M., Barker. G. L., D'Amore, R., Allen, A. M., ... Hall, N. (2012). Analysis of the bread wheat genome using whole genome shotgun sequencing. Nature, 491, 705-710. doi: 10.1038/nature11650

3. Prokopenko, 0. (Ed.). (2019). Roslynnytstvo Ukrainy 2018. Statystychnyi zbirnyk [Crop production of Ukraine 2018. Statistical year book]. Kyiv: State Statistics Service of Ukraine. [in Ukrainian]

4. Chernobai, Yu. 0., Riabchun, V. K., Yarosh, A. V., \& Morhunov, 0. I. (2019). Winter bread wheat productivity elements and yield capacity in relation to its origin. Genetični resursi roslin [Plant Genetic Resources], 24, 47-57. doi: 10.36814/pgr.2019.24.03. [in Ukrainian]

5. Khomenko, S. 0., Kochmarskyi, V. S., Fedorenko, I. V., \& Fedorenko, I. V. (2020). Breeding value of spring durum wheat accessions for performance traits under environment of Ukrainian Forest-Steppe. Plant Var. Stud. Prot., 16(3), 303-309. doi: 10.21498/2518-1017.16.3.2020.214924

6. Kyrychenko, V. V., Riabchun, V. K., \& Bohuslavskyi, R. L. (2008). Importance of plant genetic resources in realization of state programs. Genetični resursi roslin [Plant Genetic Resources], 5, 7-13. [in Ukrainian]

7. Hassan, M. S., Mohamed, G. I. A., \& El-Said, R. A. R. (2013). Stability Analysis for Grain Yield and its Components of Some Durum Wheat Genotypes (Triticum durum L.) Under Different Environments. Asian J. Crop Sci., 5(2), 179-189. doi: 10.3923/ ajcs.2013.179.189

8. Kholod, S. H. (2008). Main directions of formation and use of the panicum collection of Ustymivka Experimental Station of Plant Production. Genetični resursi roslin [Plant Genetic Resources], 6, 34-40. [in Ukrainian]

9. Hryhorashchenko, L. V., \& Rohulina, L. V. (2008). Millet sources for the protein content in the grain. Genetični resursi roslin [Plant Genetic Resources], 6, 116-122. [in Ukrainian]

10. Vaschenko, V. V., \& Nazarenko, M. M. (2014) Analysis of soft winter wheat productivity in the Northern Steppe of Ukraine. Plant Var. Stud. Prot., 4, 68-72. doi: 10.21498/25181017.4(25).2014.55977 [in Ukrainian]

11. Grogana, S. M., Andersonc, J., Baenziger, P. S., Frels, K., Guttieri, M. J., Haley, S. D., ... Byrne, P. F. (2016). Phenotypic Plasticity of Winter Wheat Heading Date and Grain Yield across the US Great Plains. Crop Sci., 56(5), 2223-2236. doi: 10.2135/ cropsci2015.06.0357

12. Juliana, P., Singh, R. P., Braun, H. J., Huerta-Espino, J., CrespoHerrera, L., Velu, G., ... Shrestha, S. (2020). Genomic Selection for Grain Yield in the CIMMYT Wheat Breeding ProgramStatus and Perspectives. Plant Sci., 11, 1-18. doi: 10.3389/ fpls.2020.564183

13. Rekomendatsii po izucheniyu zarubezhnykh obraztsov sel'skokhozyaystvennykh kultur $v$ introduktsionno-karantinnykh pitomnikakh [Guidelines for studying foreign samples of crops in the introduction-quarantine nurseries]. (1986). Leningrad: VIR. [in Russian]

14. Gradchaninova, 0. D., Rudenko, M. I., \& Filatenko, A. A. (1985). Metodicheskie ukazaniya po izucheniyu kollekcii pshenicy 
[Methodical instructions on studying a collection of wheat]. V. F. Dorofeeva (Ed.). Leningrad: VIR. [in Russian]

15. Filatenko, A. A., \& Shitova, I. P. (1989). Shirokiy unifitsirovannyy klassifikator SEV roda Triticum L. [CMEA wide-range unified classifier of the genus Triticum L.]. V. A. Korneychuk (Ed.). Leningrad: VIR. [in Russian]

16. Vavilov, N. I. (1962). Izbrannye trudy. T. 3: Problemy geografii, filogenii i selektsii pshenitsy i rzhi. Rastitel'nye resursy $i$ voprosy sistematiki kul'turnykh rasteniy [Selected Works. Vol. 3: Problems of geography, phylogeny and selection of wheat and rye. Plant resources and issues of taxonomy of cultivated plants] (pp. 166-168). F. Kh. Bakhteev \& E. N. Sinskaya (Eds.). Moscow-Leningrad: Izd-vo Akad. nauk SSSR. [in Russian]

17. Zviahin, A. F. (2011) The influence of the duration of the growing season on the date of earing on the yield of winter wheat varieties. Selekcis i nasmnnictvo [Plant Breeding and Seed Production], 100, 66-77. [in Ukrainian]

18. Kirian, V. M., Kirian, M. V., \& Vyskub, R. S. (2016). Genetic resources as initial material for developing new soft winter wheat varieties. Plant Var. Stud. Prot., 4, 10-17. doi: 10.21498/25181017.4(33).2016.88570 [in Ukrainian]

19. Kochmarskyi, V. S., Khomenko, S. O., Fedorenko, M. V., \& Daniuk, T. A. (2015). Plant heignt and lodging resistance of collection accessions of durum apring wheat. Mironivs'kij visnik [Myronivka Bulletin], 1, 73-81. [in Ukrainian]

20. Orliuk, A. P., \& Kolesnikova, N. D. (2001). Variability of winter wheat plant height among progenies of multidirectional selections. In Sovremennye problemy genetiki, biotekhnologii i selektsii rasteniy: tezisy dokl. Mezhdunar. konf. molodykh uchenykh [Modern problems of Genetics, Biotechnology and Plant Breeding: Proc. Int. Conf. young scientists] (pp. 231-232). July 2-7, 2001, Kharkiv, Ukraine. [in Ukrainian]

21. Lyfenko, S. F. (1988). Selektsiya sortov ozimoy pshenitsy intensivnogo tipa $v$ usloviyakh yuga Ukrainy [Selection of varieties of winter wheat of intensive type in the conditions of the south of Ukraine] (Extended Abstract of Dr. Agric. Sci. Diss.). Plant Breeding and Genetics Institute of UAAS, Odessa, Ukraine. [in Ukrainian]

22. Demydov, 0. A., Blyzniuk, R. M., \& Radchenko, 0. S. (2015). Characteristics of promising spring wheat lines by yield components. Mironivs'kij visnik [Myronivka Bulletin], 1, 18-25. [in Ukrainian]

23. Kholod, S. M., \& Vyskub, R. S. (2018). Characteristic of geographically distant samples of winter soft wheat from $20^{\text {TH }}$ FAWWON-SA nursery in the southern Forest-Steppe of Ukraine. Plant Var. Stu. Prot., 14(2), 144-152. doi: 10.21498/25181017.14.2.2018.134760. [in Ukrainian]

\section{Використана література}

1. Кочмарський В. С., Замліла Н. П., Вологдіна Г. Б. та ін. Рівень адаптивності перспективних ліній пшениці м'якої озимої в умовах Лісостепу України. Миронівський вісник. 2016. Вип. 2. С. 98-116.

2. Brenchley R., Spannagl N., Pfeifer M. et al. Analysis of the bread wheat genome using whole genome shotgun sequencing. Nature. 2012. Vol. 491. P. 705-710. doi: 10.1038/nature11650

3. Рослинництво України 2018. Статистичний збірник / за ред. 0. Прокопенко. Київ : Державна служба статистики України, 2019. 220 с.

4. Чернобай Ю. 0., Рябчун В. К., Ярош А. В., Моргунов 0. І. Елементи продуктивності та врожайності зразків пшениці м'якої озимої в залежності від походження. Генетичні ресурси рослин. 2019. Вип. 24. С. 47-57. doi: 10.36814/pgr.2019.24.03

5. Хоменко С. 0., Кочмарський В. С., Федоренко І. В., Федоренко М. В. Селекційна цінність колекційних зразків пшениці твердої ярої за показниками продуктивності в умовах Лісостепу України. Plant Var. Stud. Prot. 2020. T. 16, №3. С. 303309. doi : 10.21498/2518-1017.16.3.2020.214924
6. Кириченко В. В., Рябчун В. К., Богуславський Р. Л. Роль генетичних ресурсів рослин у виконанні державних програм. Генетичні ресурси рослин. 2008. № 5. С. 7-13.

7. Hassan M. S., Mohamed G. I. A., El-Said R. A. R. Stability Analysis for Grain Yield and its Components of Some Durum Wheat Genotypes (Triticum durum L.) Under Different Environments. Asian J. Crop Sci. 2013. Vol. 5, Iss. 2. P. 179-189. doi: 10.3923/ ajcs.2013.179.189

8. Холод С. Г. Основні напрями формування та використання колекції проса Устимівської дослідної станції рослинництва. Генетичні ресурси рослин. 2008. №6. С. 34-40.

9. Григоращенко Л. В., Рогуліна Л. В. Джерела проса за вмістом білка в зерні. Генетичні ресурси рослин. 2008. № 6. С. 116-122.

10. Ващенко В. В., Назаренко М. М. Аналіз продуктивності пшениці м'якої озимої в умовах Північного Степу України. Plant Var. Stud. Prot. 2014. № 4. C. 68-72. doi: 10.21498/25181017.4(25).2014.55977

11. Grogana S. M., Andersonc J., Baenziger P. S. et al. Phenotypic Plasticity of Winter Wheat Heading Date and Grain Yield across the US Great Plains. Crop Sci. 2016. Vol. 56, Iss. 5. P. 22232236. doi: 10.2135/cropsci2015.06.0357

12. Juliana P., Singh R. P., Braun H. J. et al. Genomic Selection for Grain Yield in the CIMMYT Wheat Breeding Program-Status and Perspectives. Front. Plant Sci. 2020. Vol. 11. P. 1-18. doi: $10.3389 /$ fpls.2020.564183

13. Рекомендации по изучению зарубежных образцов сельскохозяйственных культур на интродукционно-карантинных питомниках. Ленинград : ВИР, 1986. 69 с.

14. Методические указания по изучению коллекции пшеницы / сост. : О. Д. Градчанинова, М. И. Руденко, А. А. Филатенко ; под ред. В. Ф. Дорофеева. Ленинград : ВИР, 1985. 28 с.

15. Широкий унифицированный классификатор СЭВ рода Triticum L. / сост. : А. А. Филатенко, И. П. Шитова ; под ред. В. А. Корнейчук. Ленинград : ВИР, 1989. 44 с.

16. Вавилов Н. И. Избранные труды. Т. 3: Проблемы географии, филогении и селекции пшеницы и ржи. Растительные ресурсы и вопросы систематики культурных растений / отв. ред. Ф. Х. Бахтеев и Е. Н. Синская. Москва-Ленинград : Издво Акад. наук СССР, 1962. С. 166-168.

17. Звягін А. Ф. Вплив тривалості вегетаційного періоду за датою колосіння на урожайність сортів озимої пшениці. Селекція і насінництво. 2011. Вип. 100. С. 66-71.

18. Кір'ян В. М., Кір'ян М. В., Вискуб Р. С. Генетичні ресурси як вихідний матеріал для створення нових сортів пшениці м'якої озимої. Plant Var. Stud. Prot. 2016. № 4. С. 10-17. doi: 10.21498/2518-1017.4(33).2016.88570

19. Кочмарський В. С., Хоменко С. О., Федоренко М. В., Данюк Т. А., Висота рослин та стійкість проти вилягання колекційних зразків пшениці твердої ярої. Миронівський вісник. 2015. Вип. 1. С. 73-81.

20. Орлюк А. П., Колеснікова Н. Д. Мінливість висоти рослин озимої пшениці у нащадків різноспрямованих доборів. Современные проблемы генетики, биотехнологии и селекции растений : тезисы докл. Междунар. конф. молодых ученых (м. Харьків, 2-7 липня 2001 р.). Харків, 2001. С. 231-232.

21. Лыфенко С. Ф. Селекция сортов озимой пшеницы интенсивного типа в условиях юга Украины : автореф. дис. ... д-ра с.-х. наук : спец. 06.01.05 'Селекция и семеноводство' / Селекционно-генетический институт УААН. Одесса, 1988. 47 с.

22. Демидов 0. А., Близнюк Р. М., Радченко 0. С. Характеристика перспективних ліній пшениці ярої за елементами структури врожаю. Миронівський вісник. 2015. Вип. 1. С. 18-25.

23. Холод С. М., Вискуб Р. С. Характеристика географічно віддалених зразків пшениці м'якої озимої розсадника $20^{\mathrm{TH}}$ FAWWON-SA в зоні Південного Лісостепу України. Plant Var. Stud. Prot. 2018. T. 14, № 2. C. 144-152. doi: 10.21498/25181017.14.2.2018.134760 


\section{УДК 633.11:631.527}

Холод С. М. ${ }^{*}$, Кір'ян В. М. , Вискуб Р. С. Характеристика за продуктивністю зразків пшениці м'якої озимої розсадника Common Bunt-Resistant Nursery (CBUNT-RES) у зоні Південного Лісостепу України. Plant Varieties Studying and Protection, 16(4), 369-377. https://doi.org/10.21498/2518-1017.16.4.2020.224052

Устимівська дослідна станція рослинництва Інституту рослинництва ім. В. Я. Юр'єва НААН України, вул. Академіка Вавилова, 15, c. Устимівка, Глобинський р-н, Полтавська обл., 39074, Україна, "e-mail: svitlanakholod77@ukr.net

Мета. Оцінити інтродуковані зразки пшениці м'якої озимої різного еколого-географічного походження з міжнародного розсадника Common Bunt-Resistant Nursery (CBUNT-RES) в умовах південної частини Лісостепу України за комплексом показників продуктивності для виділення найцінніших зразків та скласти їнній опис. Методи. Упродовж 2016-2019 рр. в умовах Устимівської дослідної станції рослинництва Інституту рослинництва ім. В. Я. Юр'єва НААН за ознаками продуктивності досліджено, оцінено та описано 75 нових зразків пшениці м'якої озимої різного еколого-географічного походження. У польових i лабораторних умовах визначено такі показники врожайності й продуктивності, як маса 1000 зерен, висота рослин та довжина колоса, кількість колосків і зерен у колосі, маса колоса та зерна з нього, а також скоростиглість зразків. Результати. Виділено матеріал, який має підвищені параметри господарських та біологічних ознак. 30крема, до високоврожайних зразків належать: 'F08347G8', 'F00628G34-1' (Румунія), ‘91-142A61/KATIA1//GRISET-4', 'SAULESKU\#44/TR810200//GRISET-4', 'ATTILA/BABAX//
PASTOR/4/...' (IU067591) (Туреччина), 'INTENSIVNAYA// PBW343*2/TUKURU', 'SANZAR-8/KKTS' (Мексика). У зразків пшениці м'якої озимої 'F08347G8', 'F00628G34-1' (Румунія), 'INTENSIVNAYA//PBW343*2/...' (IU067637) (Мексика), 'ATAY/GALVEZ87/6/TAST/...' (IU067587), 'DE9/MERCAN-2', 'KRASNODAR/ FRTL/6...' (IU067595), 'SAULESKU\#44/ TR810200//GRISET-4', 'KRASNODAR/FRTL/6...' (IU067595), 'GANSU-1/3/AUSGS50AT34/...' (IU067598), 'DE9/MERCAN-2', 'ORKINOS-1*2/3/AUS...' (IU067608), 'KAMBARA1/ZANDER-17', 'TAM200/KAUZ/4/CHAM6//...' (IU067612) (Туреччина) маса зерна з рослини перевищувала 5,0 г, вони мають досить високі показники продуктивності рослини як завдяки підвищеній озерненості, так і масі 1000 зерен. Висновки. Інтродуковані зразки пшениці м'якої озимої різного еколого-географічного походження, виділені за комплексом цінних ознак, можна рекомендувати як вихідний матеріал у селекції на підвищення продуктивного потенціалу культури в умовах Південного Лісостепу України.

Ключові слова: пшениця м'яка озима; продуктивність; цінні господарські ознаки; вихідний матеріал.

Надійшла / Received 12.10.2020 Погоджено до друку / Accepted 25.11.2020 